\title{
Culture-specific features as determinants of news media use
}

\author{
HASIBE GEZDUCI and LEEN D'HAENENS
}

\section{Abstract}

This article, which looks at exposure to and the use of host and home media by Turkish diaspora in Belgium, illustrates that media use is determined by cultural as well as socio-demographic features. By means of a quantitative survey among four hundred respondents of Turkish origin between the ages of eighteen and sixty, the use of host and home media (i.e., old and new) in general and news contents in particular were analyzed in relation to culture-specific features such as ethnic cultural position, religion, and command of language, alongside with socio-demographic features such as age, gender, education, years of residence and socio-economic status. Our investigation showed religion, ethnic-cultural position and command of the Turkish language to be the strongest determinants for home language news media use, while host language news media use was strongly determined by command of the Dutch or French language, length of residence and educational level. These findings, especially those pertaining to news use, bring nuance to a certain number of earlier findings with Turkish youngsters in the Netherlands and Flanders (12-19), whose media use was predominantly related to socio-demographics.

Keywords: Turkish diaspora, Flanders, home and host media preferences, religion, ethnic-cultural position, news media use

\section{The Turkish diaspora's transnational communication processes}

In Flemish cities, one can spot Turkish, Moroccan and other non-western minority neighborhoods by the number of satellite dishes attached to balcony railings. Despite research on ethnic minorities', immigrants' or diasporas' ${ }^{1}$, hereafter used interchangeably, use of media suggesting that satellite channels far from discourage socio-cultural processes and are mainly used because they give minorities the chance to make meaningful cultural and informational choices, this abundance of satellite 
dishes in many suburbs upsets people and is often viewed as indicative of a lack of cultural and social integration into the host society (Staring and Zorlu, 1996; Millikowski, 1998, 1999).

Although there is a substantial amount of research available on ethnic minorities and media, the bulk of it is mostly concerned with the ways in which these ethnic minorities are portrayed in the media and little effort has been made, particularly in Europe, to determine how and why ethnic minorities use the media, for instance in terms of their potential role in the formation of social capital, such as membership association, neighborliness, civic engagement, and social trust (Beaudoin and Thorson, 2004; Norris, 1996, 2000; Shah, Kwak and Holbert, 2001; Putnam, 2000). On one hand, the host media can resolve cultural differences and can serve as a source on a nation's social and cultural heritage in the immigrants' process of learning about or adapting to the new society (Greenberg, 1983; Subervi-Velez, 1986; Messaris and Woo, 1991; Greenberg, 1994; Kim, 1995; Tan, 1998; Hall, Anten and Cakim, 1999; Viswanath and Arora, 2000; Walker, 1999; Zhou and Cai, 2002). This process has been called "bridging social capital" by Putnam (2000) and is considered a pre-requisite for social-cultural participation or integration into the host society. On the other hand, media from the home country help immigrants connect to their original culture and thus play a prominent role in the preservation of their own cultural heritage and strengthen their inter-group solidarity (Greenberg, 1983; Subervi-Velez, 1986; Greenberg, 1994; Kim, 1995; Hall, Anten and Cakim, 1999; Appadurai, 1997; Rios and Gaines, 1998; Jeffres, 2000). In this case, the function of the media concerns communication within a given cultural group. Putnam (2000) calls this process "bonding social capital".

From the above it is clear that media in the host and home language influence social capital, yet we should not forget that the preference for certain media does not occur in a vacuum but is reflective of who we are (our background such as personal values, belief systems, ethnicity), what we do (our direct, personal experiences), and what we see, hear and learn through our exposure to media (Fathi, 1973; de Mooij, 1998; Frable, 1997; Jaret and Reitzes, 1999).

That said, quantitative research in Europe on media use almost exclusively adopts common socio-demographic characteristics such as age, gender, education, and income as possible determinants for media use, while culture-specific characteristics are hardly considered as possible predictors of media use. Moreover, research that includes the cultural dimension of ethnic minorities' media use is mostly based on limited, ad hoc samples in which the predictive value of ethnic-cultural variables is assessed in isolation and not in competition with socio-demographic characteristics (e. g., Brouwer, 2001; Geense and Pels, 2002). The first of 
two research initiatives in the Netherlands and Flanders that do study both culture-specific and socio-demographic determinants on ethnic minorities' media use is a series of school surveys carried out by d'Haenens et al. (2004), in which Turkish and Moroccan youngsters' media access and use was examined. These school surveys showed that the ethniccultural position of Moroccan and Turkish youth in the Netherlands and Flanders ${ }^{2}$ had little or no predictive value with regard to access to and ownership and use of 'old' and 'new' media. However, culture-specific variables, and ethnic-cultural position in particular, did matter when looking at media use of specific user profiles (i.e., the 'homelanders' making more use of media from the home country than Dutch-language media; the 'omnivores' spending equal time on media from both the home country and the Netherlands/Flanders; and the 'adaptors', making less use of media from the home country than Dutch-language media). Regression analyses showed that the proportion of media use (both 'old' and 'new') dedicated to the home or the host country could be explained through ethnic-cultural position and knowledge of language.

The other quantitative study is the Media and Ethnic Audience Groups Survey, commissioned by the Dutch Production Fund, a part of the public broadcaster, published in 2004 and based upon the only representative sample so far of the four largest ethnic minority groups in the Netherlands: Turks, Moroccans, Surinamese and Antilleans (split into two age groups of thirteen to 24 , and 25 and above). The key issue was to find out if the socio-cultural participation or integration of these diasporas into the Dutch society had an effect on their media preferences. The construct 'integration or socio-cultural participation' had six dimensions, among which the extent to which norms and values of Dutch society were endorsed by the above stated ethnic minorities and their motivation with respect to integration (Peeters and d'Haenens, 2005). The article sought to depict immigrants' dual-track media use and to find out which media were best suited to meet the users' wishes. The results showed that integration had a positive impact on the use of Dutch language media use, in particular for the reading of newspapers and magazines, and listening to the radio. In other words, the Turks, Moroccans, Antilleans and Surinamese with a higher level of participation in the Dutch society read Dutch print media and listened to Dutch radio more than those with a lower level of participation. Watching television, however, was negatively related to the socio-cultural participation for all four ethnic minorities under study. The less they participated socially in Dutch society, the less time was spent on host language television while more 'homeland' slanted television was watched.

As for the Internet, for all groups a correlation between integration and own-group bias was found. For the Surinamese group, it was no- 
ticed that less well-integrated individuals used the Internet more often, thus making up for the unavailability of 'homeland' television programs, which Moroccans and Turks could watch via satellite dishes. Youngsters who were better integrated could therefore be expected to use media in the host language more often than those older than them, with the exception of the Internet (where the generation gap plays a role).

The results showed that well-integrated immigrants more often turned to Dutch media, but used more media time overall, so that ultimately they did not spend less time on media from their own culture. There was therefore no clash identified between bridging and bonding: as a matter of fact, in practice integration did not entail the loss of one's own cultural identity but rather a deeper involvement in the other culture. In this way, bridging and bonding go hand in hand; this is best exemplified in the use of the Internet, but it is true of all the media types examined, except for television, since watching programs with a homeland slant is done at the expense of Dutch-language programs. In light of these results, the need for more and new empirical data on diasporas in Flanders is strong.

Complementing the above research, the present study will explore culture-specific and socio-demographic features that influence Turkish adults' (i. e., between the ages of 18 and 60) selective exposure towards host and home media. The Turkish diaspora in Flanders, hereafter also called Flemish Turks, is particularly of interest as they are the second largest non-European community (second only to Moroccans) in Belgium, primarily located in Brussels, Antwerp, Ghent, the Limburg region, Charleroi and Liège. In addition, Turkish ethnic minorities are of interest as they have access to a variety of 'old' and 'new' media outlets in their native and host language, allowing them to learn about events and issues through both Western and non-Western lenses. Research reveals that Turkish immigrants indeed manifest quite a mixed use of various forms of media texts that are constantly cross-referring to, enhancing, or even negating one another. This media mix is considered more or less reflective of their cultural values, belief systems, and context-specific attitudes (Aksoy and Robins, 1997, 2000; Ogan and Milikowski, 1998; d'Haenens et al., 2004). In our paper, media preferences towards home and host media will be explored focusing on information-related functions of television, newspapers and the Internet. News, as one of the information-related kinds of content, will be dealt with in particular, because of its social function and significant impact on diaspora (Gillespie, 1995), in light of their high level of trust in news content, particularly news in which 'real images' are shown (Mullan, 1997). Moreover, the use of television news has been at the focus of mass communication research for decades (Schaap, Renckstorf and Wester, 2001). Television news is 
deemed important, because it is assumed that reading, listening and/or watching the news is indispensable for keeping people connected with the larger society (Robinson and Levy, 1986; Schudson, 1995).

Based on the understanding that culture-specific variables, socio-demographic variables, and the availability of diverse media may manifest incentives or motivations for media use, program choice and content selection by Turkish immigrants in Flanders and to make any inferences regarding these media related practices, insights are required by the uses and gratifications (Blumler and Katz, 1974) perspective, which posits that people bend the media to their needs more readily than the media overpower people. Specifically, it contends that media users have specific goals or needs in mind and actively seek out or choose and use specific media and certain content (e.g., information or entertainment) over other existing options to achieve those goals and satisfy specific psychological, social and socio-cultural needs.

\section{Determinants of media orientation}

\section{Methodology}

The objective of the current study is to explore preferences of news media use by Turkish diaspora in Flanders. Figure 1 presents the research design.

We assume that Turkish immigrants' use of host (news) media as compared to home (news) media can be explained by their culture-specific features such as ethnic-cultural position, religion, and command of the

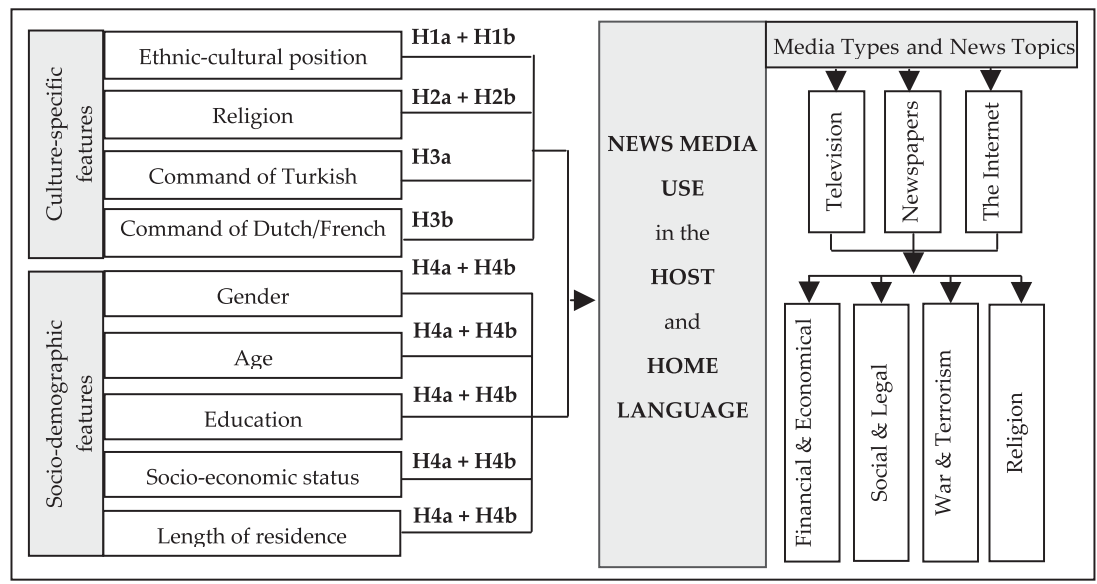

Figure 1. Research model. 
language in addition to socio-demographic features, such as age, gender, education, years of residence and social economic status, and thereby intend to answer the following research question:

To what extent do culture-specific features, alongside socio-demographic features, impact news media preferences among the Turkish diaspora in Flanders?

There are important distinctions to be made between different measures of culture-specific features alongside the socio-demographic features; assessing their relative impact on selective exposure towards media use is a central goal of this research. For the construct 'ethnic-cultural position' as one of the culture-specific determinants on Flemish Turks' media use, we were inspired by Van Heelsum's (1997) work on second-generation Surinamese living in the Netherlands. This construct measures the extent to which members of a particular group regard themselves primarily as members of a specific group (position acquisition) and the extent to which they are regarded and/or treated primarily by the majority of society as representatives of a specific group (position allocation) (Van Heelsum, 1997: 24). In the context of Turkish diaspora's home or host news media use and its linkage with ethnic-cultural position, we assume that Turkish ethnic minorities in Flanders who are favorably oriented toward people of their own ethnic group would tend to prefer home media content, whereas host media use is expected to be negatively related to the strength of one's ethnic-cultural position (i.e., orientation towards Turkey). In order to address the relation between ethnic-cultural position and preferences for news media use in the home or host language, the first hypotheses are as follows:

Hypothesis 1a: Home news media use will be positively related to the strength of the Flemish Turks' ethnic-cultural position.

Hypothesis 1b: Host news media use will be negatively related to the strength of the Flemish Turks' ethnic-cultural position.

Religion, another cultural feature often considered an essential element of the cultural heritage of the Turkish immigrants, is expected to be prominent in Flemish Turks' media use. Research done by d'Haenens et al. (2003) shows that religion is indeed a relevant predictor of ICT use among Turkish youngsters. Religion in our study is a measure of feeling towards active religious participation expressed in the Muslim context through the observation of prayer at certain times during the day (in the mosque or otherwise), reading the Koran, and actively participating in religious activities such as the Ramadan, the Eid ul-Fitr (Feast of Break- 
ing the Fast) and the Eid ul-Adha (Feast of the Sacrifice). We were inspired by Kemper's (1996) dimensions on religious identity and looked at the respondents' feelings regarding some of these dimensions (i.e., participation in and agreement with Islamic rituals, knowledge of Islamic doctrines, maintaining and practicing Islamic norms and values in daily life and the bond within the community of believers such as meetings within certain groups of believers) which are all centered around the five pillars of Islam (i. e., sjahaada, salaa, zakaa, the Shari'a, Ramadan, and haddj). To address the relation between religion and home and host news media use, the following hypotheses are formulated:

Hypothesis 2a: Home news media use will be positively related to the strength of Flemish Turks' religiousness.

Hypothesis 2b: Host news media use will be negatively related to the strength of Flemish Turks' religiousness.

An additional influence that is expected to be associated with media use is command of the home (Turkish) and host (Dutch or French) language. Research findings on bilingualism and media preference in bicultural environments suggest that ethnic minorities prefer media in the language of origin, even after having spent significant time in a new country (Delener and Neelankavil, 1990; Lee and Tse, 1994). Research from Canada indicates that patterns of media exposure in a multicultural environment are, to a large part, determined by one's degree of bilingualism (Woelfel et al., 1980; Barnett and McPhail, 1980). That is, bilinguals who speak English more frequently use English-language media, and those bilinguals who speak French to a greater degree more frequently use Francophone media. When examining the relationship between language competence and media consumption among Turkish immigrants in Flanders, we expect media preference to be related to the strength of one's knowledge of the Dutch, French or Turkish language. The following hypotheses relate to the relation between command of the home or host language and news media use from the home as well as from the host country:

Hypothesis 3a: Home news media use will be positively related to the strength of Flemish Turks' command of the home language.

Hypothesis 3b: Host news media use will be positively related to the strength of Flemish Turks' command of the host language.

In addition to the cultural background characteristics cited above, sociodemographic features have been included to explain media use. As there 
is undeniably a great diversity within the generations of the Turkish diaspora under study, indicating differences in every generation's needs, interests, alliances, perceptions and relationships towards choice of home and host media, we assume that the latter will be reflected through age, gender, education, length of residence, and socio-economic status. For the impact of age and gender on home and host media preferences, we expect age and gender to be positively related to the use of home media and negatively related to host media use. In other words, it is expected that Turkish media is more preferred by females and older Turks, whereas Dutch or French media are more preferred by males and younger Turks.

Furthermore, home media use is expected to be negatively related to the respondents' length of residence, education and socio-economic status, while host media use is expected to be positively related to these features. Thus, for length of residence we expect that Turkish media is more preferred by Turkish diaspora that are newly immigrated, while Dutch or French media is more preferred by Turks with a longer residence in Belgium. Moreover, based on Jeffres's (1983) conclusion that social status is negatively associated with home media use, we expect that Turkish media will be used more frequently by Turks with low educational levels and socio-economic status. Dutch or French media are expected to be used more frequently by Turks with higher levels of education and socio-economic status. Consequently, the following hypotheses are stated with respect to the relationship between the socio-demographic features and news media use from the home and host country:

Hypothesis 4a: Home news media use will be positively related to Flemish Turks' age and gender and negatively related to length of residence, education, and socio-economic status.

Hypothesis 4b: Host news media use will be negatively related to Flemish Turks' age and gender and positively related to length of residence, education, and socio-economic status.

\section{Data collection and instrument}

Data collection took place between February and May 2006 by initially randomly selecting and visiting places ${ }^{3}$ where a diversity of Turkish diaspora between the ages of 18 and 60 years were expected to be prominently present and by relying on a snowball effect in order to enlarge the initial selection of respondents. 
Data for this study were collected by means of a questionnaire, designed with the main goal of providing an initial map of host and home language media use among Turkish diaspora in Flanders. The questionnaire was developed in Turkish and Dutch in order to give the respondents the option to choose the version they felt most familiar with. Moreover, extensive pretests were conducted, by the researchers as well as by bilingual Turks, to make sure that the questionnaire contained clearly formulated questions and answers. In an effort to maximize response rates, the questionnaires were completed in person: 400 respondents (i.e., approximately one hundred in each of the four regions identified) completed the questionnaire (275 in Turkish and 125 in Dutch).

The first part of the survey aimed at obtaining preferences of home and host media use of three media types (i. e., television, newspapers and the Internet) in general and in terms of their main functions (i.e., entertaining, informational and communicative) and four news types in particular (i.e., financial and economical, social and legal topics, war and terrorism topics and topics related to religion). For television, respondents indicated how often they turned to informational (e.g., talks shows, documentaries, news programs) and entertainment (e.g., musical programs, movies, game shows) programs and in what language they preferred to watch these programs. Questions on newspaper use included only informational topics (e. g., four news topics). As the Internet offers a wide range of applications, it was thought necessary to have the respondents indicate how often they turned to each of the three major Internet activities, i. e., information (surfing the Net to retrieve information), entertainment (games, watching DVD's, downloading music, listening to music) and communication (e-mail, chat, news groups). All media use variables were measured on a five-point scale, in which a high score corresponded with a high level of use of news contents. Reliability analyses on the items containing news media-related practices included 205 items in total $(\alpha=0.958)$, among which $71 \mathrm{TV}$ items $(\alpha=0.882), 41$ newspaper items $(\alpha=0.89)$ and 65 Internet items $(\alpha=0.95)$.

Questions about 'ethnic-cultural position' were based on Van Heelsum's (1997) statements relating to the dimensions of cultural identity. Subjects had to indicate to what extent they regarded themselves as members of the Turkish community and the extent to which they were regarded and/or treated primarily by the majority of society as representatives of the Turkish community. The statements used were based on self-identification (i. e., the extent the respondents feel or see themselves as Turkish), orientation towards Turkish people (i. e., the level of commitment towards Turkish society), orientation towards Belgians (i. e., the level of commitment towards Belgian society), and contact with the own group. These statements were measured on a five-point scale ranging 
from one (strongly disagree) to five (strongly agree). High scores corresponded with a high level of involvement with the country of origin and the perception of great differences between one's own Turkish minority group and the Flemish majority group. The ethnic-cultural position measure included 23 items for which reliability analysis indicated a high Cronbach's alpha coefficient of 0.759 .

'Religiousness' was looked at from different angles asking several questions inspired on Kemper's (1996) dimensions of religious identity. These questions looked into the respondents' attitudes towards the following dimensions: the ritual dimension (i. e., the level of participation in Islamic rituals), the intellectual dimension (i. e., knowledge of the five pillars of Islam), the social dimension (i. e., meetings within certain groups of believers), the ideological dimension (i. e., level of agreement with fundamentalism, Shari'a) and the consequential dimension (i.e., practicing Islamic norms and values, such as marriage preferences, social control, and halal/haram issues). The construct religiousness which contained thirteen items on religious identity, measured on a five-point scale and coded so that a high score corresponded with a high level of religion, showed a high reliability $(\alpha=0.891)$.

The subjects' language competence was measured by 24 questions on linguistic fluency in different practical situations in which one may speak, write, read, and understand Turkish, Dutch or French. These contexts included formal and informal, public and private situations such as interactions with friends and family, at school or at work, at the doctor's office, in the city hall or consulate, reading the newspaper, watching TV, writing a letter, and filling out forms. A five-point Likert scale was used: high scores corresponded with a high level of command of the language in question. Reliability analysis with regard to the 24 items measuring command of language showed a Cronbach's alpha coefficient of 0.836 .

In addition to culture-specific characteristics, respondents were asked questions on socio-demographics such as age, gender, education, length of residence, and socio-economic status.

\section{Results}

In this section, the results of the analyses conducted to answer the research question are presented. In doing so, we distinguish between home and host media use in general and news use in particular. However, before giving the results on media use in general and news media preferences in particular, the overall characteristics of our sample are as follows. As shown in Table 1, the average age was 33 years and the average education level was secondary school. Exception made of those individ- 
Table 1. Socio-demographic characteristics.

\begin{tabular}{lllrrl}
\hline & & Scales & $N$ & Percent & Average \\
\hline Gender & 0 & Male & 196 & 49,00 & 0.51 \\
& 1 & Female & 204 & 51,00 & \\
\hline Age & 1 & Between 18 and 24 & 88 & 21.95 & 33 \\
& 2 & Between 25 and 33 & 123 & 30.67 & \\
& 3 & Between 34 and 42 & 107 & 26.68 & \\
& 4 & Older than 43 & 82 & 20.45 & \\
\hline Length of Residence & 1 & Less than 10 years & 84 & 20.90 & \multirow{2}{*}{19} \\
in Belgium & 2 & Between 10 and 20 years & 53 & 13.20 & \\
& 3 & Between 21 and 30 years & 60 & 15.00 & \\
& 4 & Longer than 30 years & 55 & 13.70 & \\
& 5 & Born in Belgium & 148 & 36.90 & \\
Education & 1 & No & 24 & 5.99 & \multirow{2}{*}{3} \\
& 2 & Primary school & 63 & 15.71 & \\
& 3 & Secondary school & 101 & 25.19 & \\
& 4 & College & 96 & 23.94 & \\
& 5 & University & 116 & 28.93 & \\
\hline Socio-economic Status & 1 & Very low & 83 & 20.70 & 2.42 \\
& 2 & Low & 142 & 35.41 & \\
& 3 & Medium & 98 & 24.44 & \\
& 4 & High & 19.20 & \\
\hline
\end{tabular}

uals born in Belgium, the average length of residence among the Turkish immigrants was eighteen years. In addition, the level of socio-economic status of the respondents was low, implying high levels of unemployment and blue-collar positions (Table 1).

For the culture-specific features, ethnic-cultural position and religion (measured on a five-point scale) were recoded into respectively three categories (low, medium, and high) and four categories (no, low, medium, and high). Table 2 shows that $42.6 \%$ of our respondents' level of 'ethnic-cultural position' or involvement with Turkey is high. Those respondents highly see themselves as Turks with a high level of commitment to Turkish society and a lot of social contacts with the Turkish group. Predominant orientation towards Belgian society was $10.2 \%$, and a little less than half of the Flemish Turks $(46.8 \%)$ embrace both cultures. With regard to religion, the majority of the sample $(48.5 \%)$ was religious on a medium level, while $2 \%$ was non-religious. Concerning command of the Turkish, Dutch or French language, these measures have been categorized into four groups, i. e., no, light, medium and high command. Thirty-eight percent of the respondents indicated a high com- 
Table 2. Culture-specific characteristics.

\begin{tabular}{lrlrrl}
\hline & & Scales & \multicolumn{1}{c}{$N$} & Percent & Average \\
\hline Ethnic-cultural position & 1 & Low & 41 & 10.22 & 2.43 \\
& 2 & Medium & 188 & 46.88 & \\
& 3 & High & 171 & 42.64 & \\
\hline Religion & 1 & No & 8 & 2.00 & 3.60 \\
& 2 & Low & 47 & 11.80 & \\
& 3 & Medium & 194 & 48.50 & \\
& 4 & High & 151 & 37.80 & \\
\hline Command of Turkish & 1 & No & 4 & 1.00 & 3.25 \\
& 2 & Low & 46 & 11.47 & \\
& 3 & Medium & 197 & 49.13 & \\
\hline Command of Dutch or French & 4 & High & 153 & 38.15 & \\
& 1 & No & 11 & 2.743 & 3.20 \\
& 2 & Low & 71 & 17.70 & \\
& 3 & Medium & 146 & 36.41 & \\
& 4 & High & 172 & 42.89 & \\
\hline
\end{tabular}

mand of the Turkish language, while $11.4 \%$ declared to have acquired a low level of Turkish language skills. All in all, the respondents considered themselves slightly more proficient in Dutch or French than Turkish.

\section{Media use in general}

In the following, as depicted in Table 3, we examine the home and host use of three media types in general and in terms of their main functions: television (entertaining and informational), newspapers (informational), and the Internet (informational, entertaining, and communicative). In addition, preferences of home and host media use of four news types in particular are examined (i. e., financial and economical topics, social and legal topics, war and terrorism topics, topics on religion).

As shown in Table 3, television is used by all respondents, while reading newspapers accounts for $55.75 \%$ of the respondents and using the Internet for $44.75 \%$. In addition, respondents tend to use media more often in Turkish than in Dutch or French, irrespective of media type and content with the exception of viewing, reading and online consulting social and legal issues. The analysis for television use in total showed that informational programs $(50.06 \%)$ are watched slightly more than entertainment programs. Among the Internet users, respondents tend to use the Internet more often for communication and entertainment purposes than for information. Concerning preference on the informational programs, respondents tend to prefer news on religious topics 


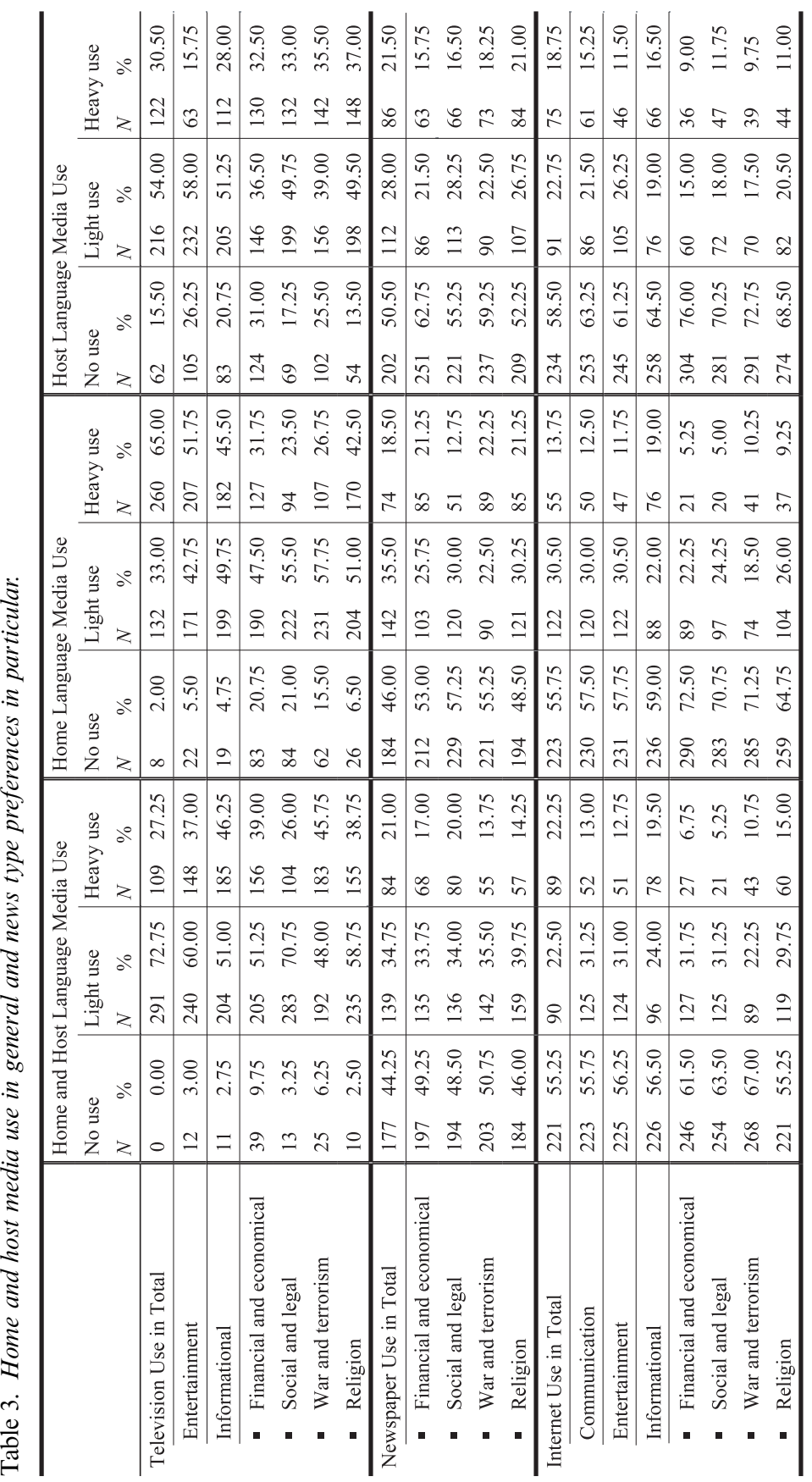


followed by social and legal topics on all three media types in both the home and host language. As to the quantity of consumption, Table 3 indicates that the respondents are light users of all three media types irrespective of media content in both home and host language.

\section{Turkish immigrants' selective use of home and host news media}

In order to investigate the factors (i. e., ethnic-cultural position, religion, command of Turkish, command of Dutch or French, gender, education, length of residence and socio-economic status) that may have an influence on the preference of media in the home and host language, hierarchical multiple regression analyses were conducted. The consumption of the four news topics on each of the three media types in the home and host language served as dependent variables. The five socio-demographic variables were entered on step 1, and the three culture-specific variables were entered simultaneously as predictors on step 2 to assess the impact of these features on home and host news media use. The hypotheses were assessed using standardized beta weights. The scores (i. e., $R^{2}$, adjusted $R^{2}, R_{\text {change, }}^{2} F_{\text {change, }}$ Sig. $\left.F_{\text {change }}\right)$ allowed us to formulate an answer to our main research question, indicating a lower or higher impact of socio-demographic or culture-specific features on home and host news media use (see Tables 4 and 5).

Our first hypothesis stated that exposure to news media in the home language would be positively related to the strength of the Flemish Turks' ethnic-cultural position (i. e., one's bond with Turkey and Turks). As shown in Table 4, ethnic-cultural position $(\beta=.217, p \leq .001)$ was indeed a positive and significant factor in predicting all kinds of media use in the home language. This means that the higher the level of empathy felt with the own group, the more Turkish language news media are used. Although this holds true for television $(\beta=.205, p \leq .001)$ and newspaper use $(\beta=.240, p \leq .001)$ in the home language, we did not find a significant relation between ethnic-cultural position and online news use, except for consulting topics on war and terrorism $(\beta=.146$, $p \leq .01)$ and religion $(\beta=.080, p \leq .05)$. As to television and newspaper use in the home language, we found ethnic-cultural position to be positively significant for all four news topics (Table 4). In other words, the higher one's orientation to Turkey and Turks, the more one tends to watch and read all kinds of news and consult online news on war and terrorism in Turkish. Thus, as ethnic-cultural position of the Turkish diaspora predicts the consumption of news on television, in newspapers, and partially predicts online news in the home language, we can conclude that hypothesis 1a is partially supported. 
Culture-specific features as determinants of news media use

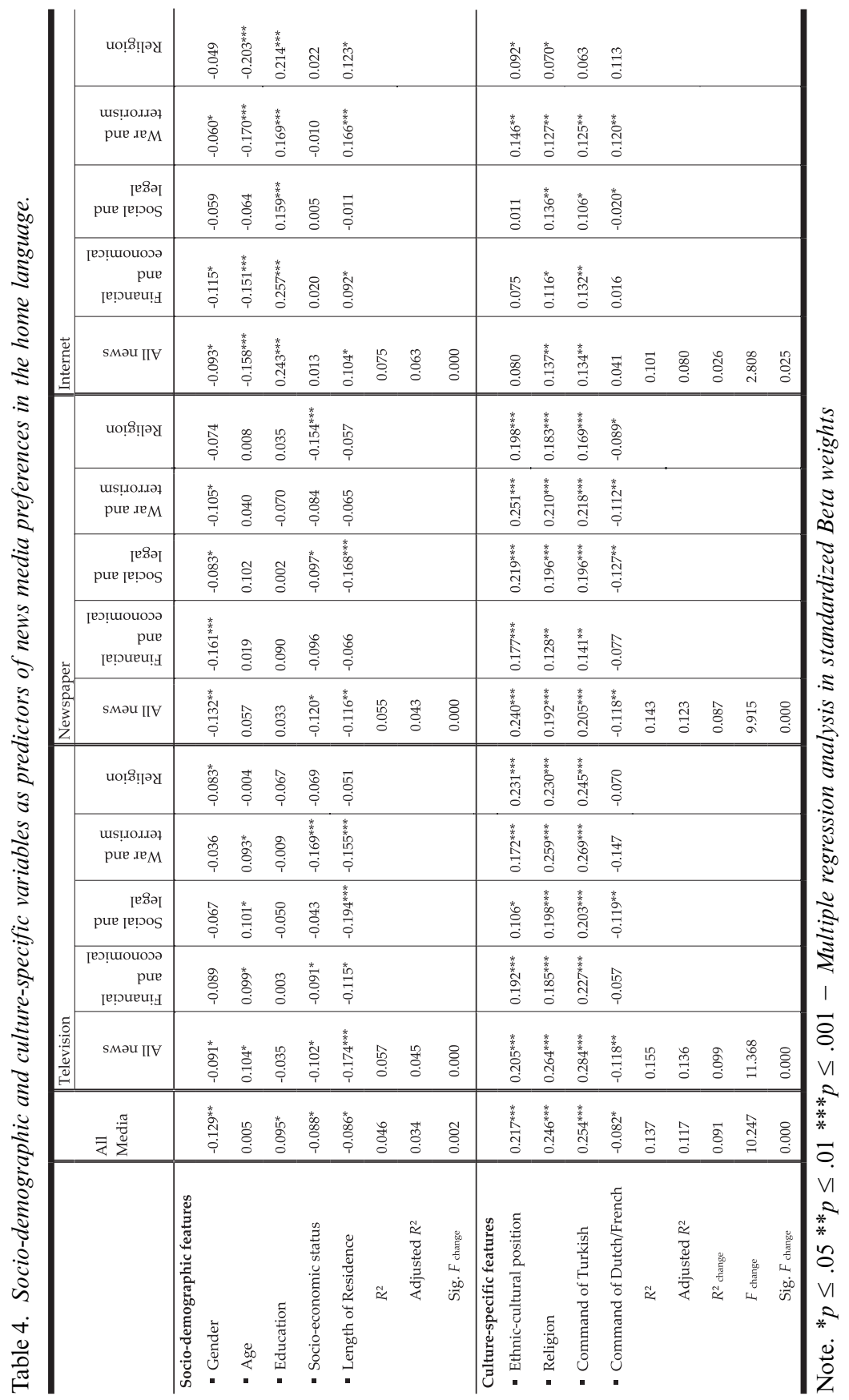




\begin{tabular}{|c|c|c|}
\hline ио:8ाँचу & 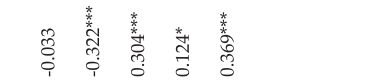 & 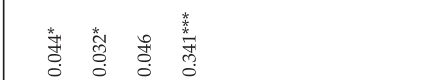 \\
\hline 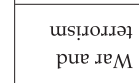 & 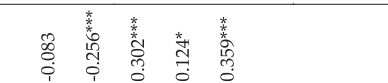 & 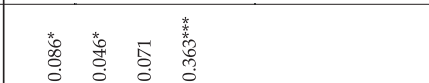 \\
\hline 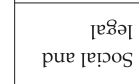 & 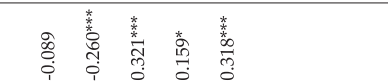 & 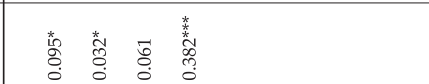 \\
\hline 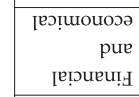 & 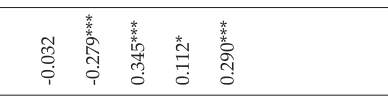 & 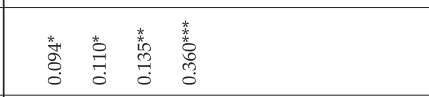 \\
\hline вмәи пा & 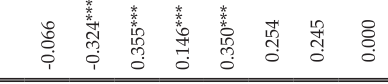 & 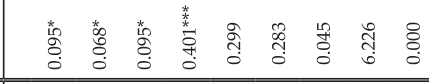 \\
\hline นо! & 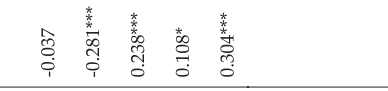 & 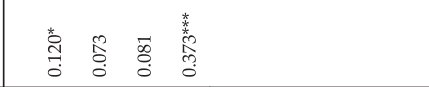 \\
\hline $\begin{array}{l}\text { usıцондағ } \\
\text { pue хемM }\end{array}$ & 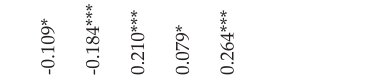 & 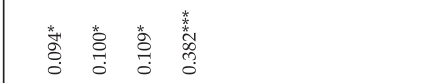 \\
\hline 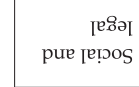 & 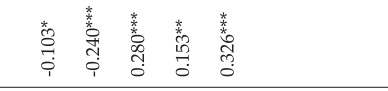 & 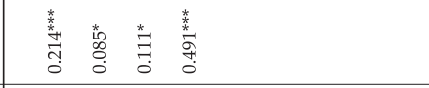 \\
\hline 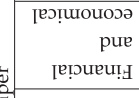 & 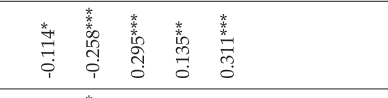 & 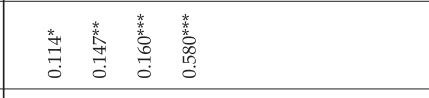 \\
\hline змәи ІІУ & 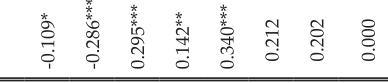 & 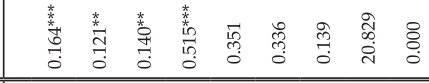 \\
\hline 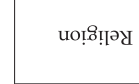 & 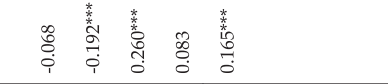 & 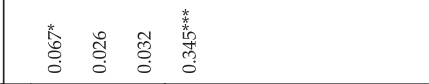 \\
\hline 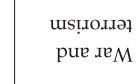 & 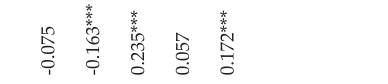 & 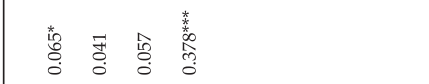 \\
\hline 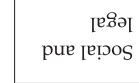 & 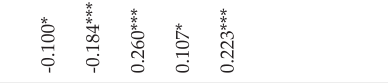 & 畨 \\
\hline 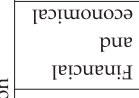 & 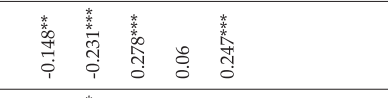 & 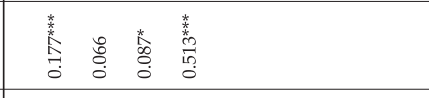 \\
\hline смәи ІІV & 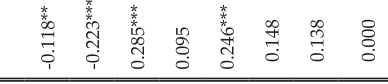 & 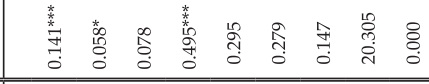 \\
\hline$\sum \frac{\tilde{\pi}}{\pi}$ & 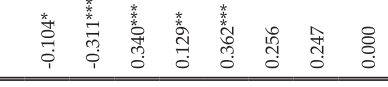 & 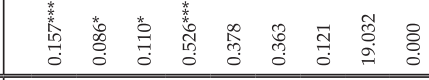 \\
\hline & 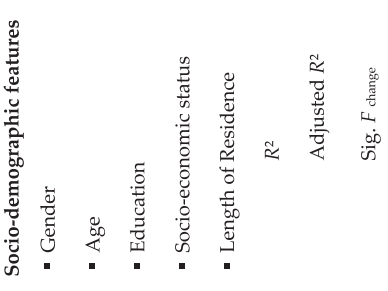 & 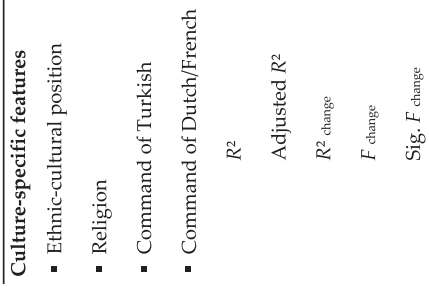 \\
\hline
\end{tabular}


For hypothesis $1 \mathrm{~b}$ we expected host news media use to be negatively related to the ethnic-cultural position of the Turkish immigrants in Flanders. This hypothesis was not supported since, quite on the contrary as shown in Table 5 , ethnic-cultural position positively $(\beta=.157, p \leq .001)$ predicted overall news media use, television viewing $(\beta=.141, \mathrm{p} \leq .001)$, newspaper reading $(\beta=.164, p \leq .001)$, and Internet use $(\beta=.095$, $p \leq .05$ ) in the host language. Moreover, with regard to the specific news topics, we found ethnic-cultural position to be a significant predictor for the consumption of all four news topics on television, newspapers and the Internet in the host language (Table 5). Consequently, these findings do not support hypothesis $1 \mathrm{~b}$.

Following hypothesis $2 \mathrm{a}$, we expected that news media in the home language would be positively related to the level of religiousness of the Turkish immigrants in Flanders. As shown in Table 4, we found a positive and significant relation between religion and home news media use $(\beta=.246, p \leq .001)$ in general. This means that highly religious Turks use media in the home language more than Turkish individuals with a lower level of religiousness. Furthermore, from regression analysis results on each media type, religion was also found a significant predictor for television exposure $(\beta=.264, p \leq .001)$, newspaper reading $(\beta=.192$, $p \leq .001)$ and Internet use $(\beta=.137, p \leq .01)$ in the home language. Turning to the specific news topics on television, newspapers and on the Internet, we found religion to be a significant predictor for the consumption of all four news topics in the home language (Table 4). Thus, irrespective of the media vehicle and the news type under study, the home language media tends to be preferred by Turkish individuals with a higher level of religiousness. Therefore, we can conclude that Turkish immigrants' religion is a good predictor for their news media use in the home language: the more religious one is, the more news is watched, read and consulted in Turkish. Hence, these findings support hypothesis $2 \mathrm{a}$.

According to hypothesis $2 \mathrm{~b}$, news media use in the host language was expected to be negatively related to religion. However, the figures in table 5 illustrate that religion is positively related to the overall news media use $(\beta=.086, p \leq .05)$ (Table 5$)$. In other words, Turkish individuals with a higher level of religiousness do not consume less but instead more news in the host language than those Turkish immigrants with a lower level of religiousness. Furthermore, a positively significant relation was also found between religion and the overall television $(\beta=.058$, $p \leq .05)$, newspaper $(\beta=.121, p \leq .01)$ and Internet $(\beta=.068, p \leq .05)$ use in the host language. With respect to the consumption of particular news topics, a significantly positive relation was found for newspaper reading and Internet use in the host language, while no relation was found for the consumption of these particular news topics on television 
(Table 5). As reading newspapers and using the Internet in the host language is more preferred by Turkish people with a high level of religiousness, we can conclude that hypothesis $2 \mathrm{~b}$ is not supported.

Hypothesis $3 \mathrm{a}$ was set out to find a positive relationship between home media use and one's command of the home language. Regression analysis revealed a significantly positive relationship between the overall home media use $(\beta=.254, p \leq .001)$ and one's command of the home language (Table 4). In other words, Turkish media are used more often by Turkish immigrants with a higher command of Turkish. More specifically, a positive and significant relation was found between command of the home language and the overall use of television $(\beta=.284, p \leq .001)$, newspaper $(\beta=.205, p \leq .001)$, and the Internet $(\beta=.134, p \leq .01)$ in the home language. Looking more in detail, we did find command of Turkish to be a significant predictor for all four news topics on all three media types, except consulting Turkish websites on religious topics (Table 4). Thus, irrespective of the medium type and content one is exposed to, except Turkish websites that are religiously tinged, Turkish is preferred to Dutch or French by individuals with a higher command of Turkish. Hence, hypothesis $3 \mathrm{a}$ is confirmed.

For hypothesis $3 \mathrm{~b}$, we expected host news media to be positively related to the strength of the Turkish immigrants' command of the host language. In other words, the use of Dutch or French language media is expected to be used more by Turkish individuals with a better command of the Dutch or French language. In addition to a positively significant relation $(\beta=.526, p \leq .001)$ between one's command of the host language and the overall host media use, table 5 shows that this holds true for all four news topics irrespective of the medium type under scrutiny: television $(\beta=.495, p \leq .001)$, newspapers $(\beta=.515, p \leq .001)$ and the Internet $(\beta=.401, p \leq .001)$ (Table 5). As such, exposure to television, newspaper and Internet content in Dutch or French tends to increase when Turks have a better command of the host language. Consequently, hypothesis $3 \mathrm{~b}$ is supported.

Our final hypotheses $4 \mathrm{a}$ and $4 \mathrm{~b}$ deal with the relation between home and host media use and socio-demographic variables. For hypothesis $4 \mathrm{a}$, we expected home news media use to be positively related with age and gender, while it was assumed to be negatively related to the length of residence, the educational level, and the socio-economic status of Turkish immigrants in Flanders. According to hypothesis $4 \mathrm{~b}$, host media use was expected to be negatively related to age and gender, and positively related with the length of residence, the educational level, and the socio-economic status of our Turkish respondents. Thus, we expected that Turkish news media are more preferred by older and female Turks, whereas Dutch or French news media are expected to be turned to 
mainly by younger Turks and males. In addition, we predicted a higher use of Turkish news media by Turkish individuals who are relatively new immigrants, characterized by a lower education level and a low socioeconomic status. A higher use of news media in Dutch or French is expected among Turkish individuals with a longer resident status in Belgium and those born in Belgium, individuals with a high socio-economic status and a high educational level.

As shown in Tables 4 and 5 , gender is negatively related to both home $(\beta=-.129, p \leq .01)$ and host $(\beta=-.104, p \leq .05)$ news media use, which means that generally speaking, Turkish men use both Turkishlanguage media and Dutch- or French-language media more often than Turkish women do. Among the home media users we found a significantly negative relation between gender and all three media types (Table 4). More specifically, a negatively significant relation was found between gender and the consumption of financial and economical, war and terrorism news topics on Turkish newspapers and Turkish websites, whereas gender was only a good predictor for religious news topics on Turkish television and social and legal news topics on Turkish newspapers.

For the host media users, gender was found to be negatively related to television $(\beta=-.118, p \leq .01)$ and newspapers $(\beta=-.109, p \leq .05)$ use, while no significant relation was found for Internet use in the host language (Table 5). Thus, results disclose that men more than women prefer Dutch- or French-language television and newspapers. As to the use of specific news topics in the host language under study, we found that Turkish men prefer to watch television on financial and economical, and social and legal news topics in Dutch or French. Among the newspaper readers, men preferred to read news on financial and economical, social and legal, and war and terrorism topics in Dutch or French (Table 5).

The age variable, as shown in Tables 4 and 5, had no significant relation with the overall media use in the home language, whereas it was negatively related to the overall media use in the host language $(\beta=$ $-.311, p \leq .001)$. In other words, Dutch- or French language media is more favored by younger Turkish individuals than older people, whereas overall use of Turkish media cannot be predicted by the age of Turkish individuals. However, when we look closer into the use of specific media types in the home language, we discover that age is positively related with television use $(\beta=.104, p \leq .05)$ and negatively related with Internet use $(\beta=-.158, p \leq .001)$; no relation was found for newspaper use. In other words, Turkish television is more preferred by older Flemish Turks, whereas consulting Turkish websites is more preferred by younger Flemish Turks. With regard to the specific news topics watched 
on television in the home language, age was found to be positively significant for financial and economical, social and legal, and war and terrorism topics. Moreover, age turned out to be negatively related with Internet use for retrieving information on financial and economical, war and terrorism and religious news topics in the home language (Table 4).

In addition to a negatively significant relation between age and the three media types, we also found age to be a good predictor for watching, reading or online consulting all four news topics in the host language (Table 5). In other words, Dutch or French media, irrespective of the media type and the content are viewed, read and consulted more often by younger than older Turkish individuals. Departing from these results, we can conclude that television, newspapers and the Internet in Dutch or French are more prominent in younger people's media menus.

When it comes to education, a positively significant relation is found between education level and news media in the home language $(\beta=.095$, $p \leq .05)$ as well as for news media use in the host language $(\beta=.340$, $p \leq .001$ ). However, with regard to the use of the media types and news types in the home language, regression analysis showed a positively significant relation between education and Internet use in the home language $(\beta=.243, p \leq .001)$ for all four news topics, whereas no significant relation was found for television viewing and newspaper reading on these news topics (Table 4). Hence, television and newspaper use in the home language is not related to education, while the use of Turkishlanguage websites is predicted by the level of education. This means that highly educated Turks turn more often to Turkish-language websites to inform oneself about all of the four news topics under study more frequently than Turkish individuals with a lower level of education.

Among host media users, we found education to be positively related to television $(\beta=.285, p \leq .001)$, newspapers $(\beta=.295, p \leq .001)$ and Internet $(\beta=.355, p \leq .001)$ use in the host language (Table 5$)$. In addition, results on the specific news topics used by the three host language media types revealed that all news topics under study were positively related to education (Table 5). As such, we can conclude that news media use in Dutch or French is highly dependent on the level of education, meaning that the higher the education level the more open Turkish immigrants tend to consume news topics on either of the three host language media types.

As shown in Tables 4 and 5, socio-economic status has a negatively significant $(\beta=-.088, p \leq .05)$ relation to the overall media use in the home language and is positively related to the overall media use in the host language $(\beta=.129, p \leq .01)$. Furthermore, regression analysis results on media types in the home language show a negative relation between socio-economic status and television viewing $(\beta=-.102$, 
$p \leq .05)$ on the one hand and newspaper reading $(\beta=-.120, p \leq .05)$ on the other (Table 4). Results about particular news topic preferences show lower socio-economic status to be a predictor for a preference for financial and economical, and war and terrorism news topics on Turkish television (Table 4). In addition, results show that the less affluent Turks tended to be the more they oriented themselves towards Turkish newspaper articles on social and legal, and religious topics.

Although socio-economic status was positively related to the general media use in the host language, this positive relation became only visible for newspaper reading $(\beta=.142, p \leq .001)$ and Internet use $(\beta=.146$, $p \leq .001)$ in the host language, while it did not have an effect on television viewing in general (Table 5). Furthermore, regression analysis results on the specific news topics disclosed that the more affluent Turks tended to be, the more often Dutch or French newspapers were read and Dutch or French websites were consulted on all four news topics (Table 5). Although results on host language media showed no relation between socio-economic status and television use in the host language, we did find that mainstream Dutch or French language television providing news on social and legal affairs were preferred by the more affluent Turks (Table 5).

For the length of residence, regression analysis results on the overall home news media use showed a negatively significant relation $(\beta=$ $-.086, p \leq .05)$, while overall host language news media use $(\beta=.362$, $p \leq .001)$ is positively and significantly related to the Turkish immigrant length of residence in Belgium. Thus, Turkish news media are used more by newly immigrated Turks, while Dutch or French media is used more by Turkish individuals with a longer residence period in Belgium and those born in Belgium. Furthermore, regression results showed that television viewing $(\beta=-.174, p \leq .001)$ and newspaper reading $(\beta=-.116$, $p \leq .01)$ in the home language in general are negatively related to length of residence, while positively related to Internet use $(\beta=-.174$, $p \leq .05)$. In other words, the shorter the residence period in Belgium, the heavier the television viewing and newspaper reading especially of news with a 'homeland' slant, whereas Internet in the home language is more preferred by longer time residents and those born in Belgium In addition, significant relations with regard to the news topics in the home language were found. Turkish newspapers were relatively more consulted for keeping abreast with social and legal topics $(\beta=-.168, p \leq .001)$ by relatively 'newcomers', whereas the Internet kept its prominence for information on financial and economical, war and terrorism and religious topics $(\beta=.123, p \leq .05)$ among longer-time residents in Belgium.

Furthermore, regression analysis results showed length of residence to be significantly positive for the use of all three media types in the host 
language: television $(\beta=.246, p \leq .001)$, newspapers $(\beta=.340, p \leq .001)$ and the Internet $(\beta=.350, p \leq .001)$, irrespective of the news topic consulted (Table 5). This means that all three media types in Dutch or French are preferred by Turkish individuals with a longer resident status in Belgium (independently of age) and those Turks born in Belgium, as opposed to the newer immigrants. In accordance with the results on home media use, we can state that Turkish television on issues as varied as financial and economical, social and legal topics, and war and terrorism as well as Turkish-language newspapers on social and legal topics, and online information on war and terrorism and religion are favored among the longer residents in Belgium and those Turks born in Belgium.

Wrapping up the results for hypotheses $4 \mathrm{a}$ and $4 \mathrm{~b}$, we can state that the former is not supported. Gender was negatively related to home language television, newspaper and Internet use. Age was negatively related to Internet use and positively related to television use in the home language. Among the higher educated individuals, more Turkish-language Internet pages were consulted, and lower socio-economic status predicted more television viewing and newspaper reading in Turkish. A shorter period of residence in Belgium predicted the preference of television viewing and Internet use in the home language. The results regarding host language media use show a negative relationship between age and gender, and a positive one with length of residence, education, and socio-economic status. We can therefore conclude that hypothesis $4 \mathrm{~b}$ is fully supported.

\section{Impact of culture-specific features on news usage patterns on home and host media}

As our research questioned the predictive value of culture-specific (i.e., religion, ethnic-cultural position, command of the home and host language) alongside socio-economic variables (i.e., age, gender, education, length of residence, socio-economic status) on Flemish Turks' news media preferences, we will now discuss the contribution of these features to the overall news use provided by all media under study and to each of the three media types separately.

With respect to the overall use of home news media (Table 4), the five socio-demographic variables entered on step one explained $3.4 \%$ of the news media use in the home language (Adjusted $R^{2}=0.034, p \leq .01$ ). The socio-demographic variables predicting home news media were gender and education followed by socio-economic status and length of residence. The three culture-specific variables entered on step two accounted for a sizable $9.1 \%$ additional variance (Adjusted $R^{2}=0.117, R^{2}$ change $=$ $\left.0.091, F_{\text {change }}=10.247, p \leq .001\right)$. Not surprisingly, command of Turkish 
weighed the heaviest on home news media use, followed by religion and ethnic-cultural position. For television in the home language, on step one the five socio-demographic variables explained $4.5 \%$ (Adjusted $R^{2}$ $=0.045, p \leq .001$ ) of the news use in the home language. Length of residence was the strongest significant marker followed by gender, age and socio-economic status. The three culture-specific features accounted for $9.9 \%$ more variance in news use on step two (Adjusted $R^{2}=0.136$, $\left.R_{\text {change }}^{2}=0.099, F_{\text {change }}=11.368, p \leq .001\right)$. In addition to command of Turkish, religion and ethnic-cultural position emerged as significant positive predictors at this step. In the case of newspaper use in the home language, the five socio-demographic variables on step one explicated $4.3 \%$ of the variance in news use in the home language (Adjusted $R^{2}=$ $0.043, p \leq .001$ ) for which gender, socio-economic status and length of residence were significant negative predictors. The three culture-specific features on step two further accounted for $8.7 \%$ on the home newspaper use variance (Adjusted $R^{2}=0.123, R_{\text {change }}^{2}=0.087, F_{\text {change }}=9.915$, $p \leq .001)$. At this stage, ethnic-cultural position, religion, and command of Turkish were significant positive predictors, and command of Dutch or French a significant negative predictor. Furthermore, results on Internet use in the home language showed that the five socio-demographic variables on step one explained $6.3 \%$ (Adjusted $R^{2}=0.063, p \leq .001$ ) of the variance in home language Internet use. Education and length of residence were significant positive predictors of Internet use in the home language, whereas age was a significant negative predictor. On step two, the three culture-specific variables explained only $2.6 \%$ further variance of Internet use in the home language (Adjusted $R^{2}=0.080, R^{2}$ change $=$ $0.026, F_{\text {change }}=2.808, p \leq .05$ ) for which religion, command of Turkish, and length of residence were significant predictors for consulting news on Turkish websites.

In the case of overall news media use in the host language, the five socio-demographic variables on step one explained $24.7 \%$ (Adjusted $R^{2}$ $=0.247, p \leq .001)$ of the host media use variance, for which length of residence, education, and age were the best predictors, followed by socioeconomic status and gender. The three culture-specific variables entered on step two explained $12.1 \%$ additional variance (Adjusted $R^{2}=0.363$, $\left.R_{\text {change }}^{2}=0.121, F_{\text {change }}=19.032, p \leq .001\right)$. The strongest culture-specific predictors were command of Dutch or French and ethnic-cultural position. The five socio-demographic variables on television use in the host language explained $13.8 \%$ (Adjusted $R^{2}=0.138, p \leq .001$ ) on step one. Education, length of residence and socio-economic status were significant positive predictors of television use in the host language, whereas age and gender were negative significant predictors. The culturespecific variables on step two contributed an additional 14.7\% (Adjusted 
$\left.R^{2}=0.279, R_{\text {change }}^{2}=0.147, F_{\text {change }}=20.305, p \leq .001\right)$ to the host television news use for which command of Dutch or French was a significant marker, followed by ethnic-cultural position and religion. Newspaper use in the host language was expounded for $20.2 \%$ (Adjusted $R^{2}$ $=0.202, p \leq .001$ ) by the five socio-demographic variables (in order of importance: education, length of residence, socio-economic status, gender and age). On step two, the three culture-specific variables further explained $13.9 \%$ (Adjusted $R^{2}=0.336, R_{\text {change }}^{2}=0.139, F_{\text {change }}=$ $20.829, p \leq .000$ ) of the variance of newspaper use in the host language. At this stage, command of Dutch and French was the most important predictor of newspaper use in the host language followed by ethniccultural position, command of Turkish and religion. Finally, the five socio-demographic variables on step one accounted for $24.5 \%$ (Adjusted $\left.R^{2}=0.245, p \leq .001\right)$ of the variance on Internet use in the host language, with a significant contribution of education, length of residence, age, and socio-economic status. On step two, the three culture-specific features explained an additional $4.5 \%$ (Adjusted $R^{2}=0.283, R_{\text {change }}^{2}=$ $\left.0.045, F_{\text {change }}=6.226, p \leq .001\right)$ of Internet news use in the host language for which command of Dutch or French was a significant predictor.

\section{Conclusions and discussion}

The question addressed in the present article was to what extent culturespecific and socio-demographic features have an impact on news media preferences among Turkish immigrants in Flanders. We sought to depict the dual-track media use among Flemish Turks in order to find out which media types are best suited to meet the users' wishes in terms of news content. Three media types (i.e., television, newspapers, Internet) and four news topics (i.e., financial and economical, social and legal issues, war and terrorism, religion) were included in the analysis. In so doing we also checked if trends in the use of media continue their course or if they have altered, dependent on the group to which one belongs in terms of socio-demographics (i.e., gender, age, education, socio-economic status, length of residence) and of culture-specific characteristics (i. e., religion, command of Turkish, command of Dutch/French, ethniccultural position). Our investigation showed that culture-specific variables have a strong impact on news media use in the media menus of Turkish residents in Flanders. More in particular, religion, ethnic-cultural position and command of the Turkish language proved to be the strongest culture-specific determinants for home language news media use, while command of the Dutch or French language and length of 
residence had the highest predictive value for host language news media use.

The findings of this study on news usage patterns are consistent with the proposition that culture-specific features are important in media choices. Turkish immigrants' culture-specific features have a greater contribution than socio-demographic features to their television news viewing, newspaper reading, and consulting online news in Turkish. Nevertheless, this contribution of culture-specific features to the use of Dutch or French media was only visible in the case of television news viewing, while socio-demographic features had a greater impact on newspaper reading and consulting online news in Dutch or French. On the one hand, ethnic-cultural position was found to be a good predictor for turning to news on TV and newspapers in the home language. In other words, the higher the connectedness with Turks and Turkey, the more one tends to watch and read about all kinds of news in Turkish. Although no significant relation was found for Internet use, a striking finding was that only online news on war and terrorism and religion seemed to be preferably consulted in Turkish by those with a high connectedness with Turks and Turkey. On the other hand, the stronger one's ethniccultural position, the more one also tends to watch, read, and consult online news in the host language. Hence, the high connectedness of the Turkish diaspora with Turkey and the use of Turkish media are not necessarily at the expense of the use of media in Dutch or French. There is therefore no clash between 'bridging' and 'bonding', as both processes go hand in hand. Furthermore, religiousness and command of Turkish prove to be strong markers for 'own' media use, although this does not exclude the use of Dutch/French language media and as such have a similar capacity of enabling people to connect with their home language news media as well as with mainstream media.

Turning ourselves now to the socio-demographics, results revealed that Turkish males more than females prefer Dutch or French television and newspapers, while no such tendency was found for the Internet. Furthermore, media outlets and news contents in Dutch or French are preferred more by Turkish people with a higher education and those Turks that are longer residents and were born in Belgium. Furthermore, the more affluent Turks tend to orient themselves more often towards media in Dutch or French, especially to newspapers and Internet sites in the host language. One last and obvious conclusion is that younger Turks prefer Dutch or French media outlets. Hence the integration of young people into 'reading society' is better than that of their elders, a finding which points to an evolution in the process of integration. Youngsters who are more integrated can certainly be expected to use general media more often than their elders. 
Set against this backdrop of preference for and reliance on the news media as shown in the present survey, more in-depth, adequate knowledge is needed of the specific needs of ethnic minorities in terms of other relevant information, on the intrinsic function of television news to provide instant information, and on ethnic minorities as interpreters of Flemish and other news media. Hence, a qualitative follow-up study has been planned in an effort to chart the overall interpretations of news media content of Turkish families (all members) in Flanders and the way they deal with diverging and not seldom incongruous world views as exposed in the television news. The assessment of television news reception will take place at three levels of analysis: the culture, the family unit, the individual. The (extended) family will be studied as a system, although we realize that families do not act as harmonious groups in most of their television viewing. Whether one is male or female, young or old, religiously active or not, predicts differences in reception of news items. The influence that culture has in terms of how Turkish men and women negotiate while viewing and interpreting television news, the role of the grandparents and the position of the youngsters as intermediaries between western and non-western cultures will be taken into further consideration.

\section{Notes}

1. Diaspora identity is characterized by a tension between relations of belonging to some kind of original home or nation, now left behind, and to the place where one has now settled down and the larger, usually national, community found there (Clifford, 1997; Cohen, 1997; Gilroy, 1996).

2. Flanders is one of the three (i. e., Flemish, French and German speaking) communities and three (i. e., Flanders, Brussels Capital, Wallony) regions of Belgium.

3. These places included mosques, Turkish conservative associations, Turkish coffee houses, Turkish secular associations, Turkish women's associations, Turkish university associations, Flemish integration offices, continuous education centers and Turkish families in three Flemish provinces (i.e., Antwerp, West-Flanders, and Limburg) and in the capital of Brussels.

\section{References}

Aksoy, A. and Robins, K. (1997). Peripheral vision: Cultural industries and cultural identities in Turkey. Environment and Planning A, 29(1), 1937-1952.

Aksoy, A. and Robins, K. (2000). Thinking across spaces: Transnational television from Turkey. European Journal of Cultural Studies, 3(3), 345-367.

Anderson, J. (2000). The Internet and Islam's new interpreters. In D. Eickelman, and $\mathrm{J}$. Anderson, New media in the Muslim world. The emerging public sphere (pp. 4157). Bloomington: Indiana University.

Anderson, J. (2000). New media in the Muslim world. The emerging public sphere. Bloomington: Indiana University. 
Appadurai, A. (1996). Modernity at large: Cultural dimensions of globalization. Minneapolis: University of Minnesota.

Barnett, G. A. and McPhail, T. L. (1980). An examination of the relationship of U.S. television to Canadian identity. International Journal of Intercultural Relations, 4, 219-232.

Beaudoin, C. E. and Thorson, E. (2004). Social capital in rural and urban communities: Testing differences in media effects and models. Journalism and Mass Communication Quarterly, 81(2), 378-399.

Beaudoin, C. E. and Thorson, E. (2004). Testing the cognitive mediation model: The roles of news reliance and three gratifications sought. Communication Research, 31 (4), 446-471.

Beentjes, J., d'Haenens, L., Van der Voort, T., and Koolstra, C. (1999). Dutch and Flemish children and adolescents as users of interactive media. Communications: the European Journal of Communication Research, 24(2), 145-66.

Brody, E. W. (1991). Managing communication processes. New York: Praeger.

Brouwer, L. (2001). Islam op internet. Een virtuele soek. In E. Bartels, A. van Harskamp and H. Wels (Eds.), Cultuur maken, cultuur breken [Culture makes, culture breaks] (pp. 35-46). Delft: Eburon.

Clifford, J. (1997). Routes: Travel and translation in the late twentieth century. Cambridge, MA: Harvard University.

Cottle, S. (Ed.) (2000). Media research and ethnic minorities: Mapping the field. Ethnic minorities and the media - changing cultural boundaries. Buckingham: Open University Press.

Cohen, R. (1997). Global diasporas. London: UCL Press.

D'Haenens, L., Beentjes, J. W. J., and Bink, S. (2000). The media experience of ethnic minorities in the Netherlands: A qualitative study. Communications, 25(3), 325-41.

D'Haenens, L., Van Summeren, C. and Saeys, F. (2003). Marokkaanse en Turkse jongeren in Nederland en Vlaanderen gaan digitaal. De rol van de etnisch-culturele positie bij de toegang tot en het gebruik van ICT [Moroccan and Turkish youths go digital. The role of ethnic-cultural position in terms of access to and use of ICT]. Migrantenstudies, 4, 201-214.

D'Haenens, L., Van Summeren, C., Saeys, F., and Koeman, J. (2004). Integratie of identiteit? Mediamenu's van Turkse en Marokkaanse jongeren [Integration or identity? media menus of Turkish and Moroccan youngsters]. Amsterdam: Boom.

De Mooij, M. K. (1998). Global marketing and advertising: Understanding cultural paradoxes. Thousand Oaks, CA: Sage.

Dyer, G. (1982). Advertising as communication. London: Methuen.

Delener, N. and Neelankavil, J. (1990). Informational sources and media usage: A comparison between Asian and Hispanic subcultures. Journal of Advertising Research, 30(3), 45-52.

Fathi, A. (1973). Mass media and a Moslim immigrant community in Canada. Anthropologica, 15, 201-230.

Frable, D. E. S. (1997). Gender, racial, ethnic, sexual, and class identities. Annual Review of Psychology, 48, 139-162.

Geense, P. and Pels, T. (2002). Allochtone jongeren op het internet [Ethnic minority youth on the Internet]. Migrantenstudies, 18(1), 2-18.

Gillespie, M. (1995). Television, ethnicity and cultural change. London: Routledge.

Gilroy, P. (1996). 'Diasporaen og identitetens omveje' [Diaspora and the detours of identities]. Social Kritik (Copenhagen) 45/46, 19-41.

Greenberg, B. (1994). Minorities and the mass media: 1970s to 1990s. In J. Bryant and D. Zillmann (Eds.), Media effects: Advances in theory and research. Hillsdale, N. J.: Lawrence Erlbaum Associates. 
Greenberg. B., Burgoon, M., Burgoon, J., and Korzenny, F. (1983). Mexican Americans and the mass media. Norwood, NJ: Ablex Publishing.

Hall, A., Anten, T., and Cakim, C. (1999). Perceived typicality: American television as seen by Mexicans, Turks, and Americans. Critical Studies in Mass Communication, 16(4), 436-455.

Hall, S. (1993). 'Encoding, decoding.' In S. Durin (Ed.), The Cultural Studies Reader (pp. 90-103). New York: Routledge.

Jaret, C. and Reitzes, D. C. (1999). The importance of racial-ethnic identity and social setting for blacks, whites and multiracials. Sociological Perspectives, 42, 711-748.

Jeffres, L. (1999). The impact of ethnicity and ethnic media on presidential voting patterns. Journalism and Communication Monographs, 1, 197-262.

Jeffres, L. (2000) 'Ethnicity and ethnic media use'. Communication Research, 27, $496-534$.

Jeffres, L. (1983). Media use for personal identification: linking uses and gratifications to culturally significant goals. Mass Communication Review, 10, 6-22.

Katz, E., Gurevitch, M., and Haas, X. (1973). On the use of mass media for important things. American Sociological Review, 38 (g), 31-65.

Katz, E., Blumler, J. G., and Gurevitch, M. (1974). Ulilization of mass communication by the individual. In J. G. Blumler and E. Katz (Eds.), The uses of mass communications: Current perspectives on gratifications research (pp. 19-32). Beverly Hills: Sage.

Katz, E., Blumler, J., and Gurevitch, M. (1974a). Utilization of mass communication by the individual. In J. G. Blumler and E. Katz (Eds.), The uses of mass communications: Current perspectives on gratifications research. Beverly Hills and London: Sage Publications.

Katz, E., Blumler, J., and Gurevitch, M. (1974b). Uses of mass communication by the individual. In W. P. Davison and F. T. C. Yu (Eds.), Mass communication research: Major issues and future directions (pp. 11-35). New York: Praeger.

Katz, E., Blumler, J. and Gurevitch, M. (1999). Utilization of mass communication by individual. In J. Hanson and D. Maxcy (Eds.), Sources notable selections in mass media (pp. 51-59). Guilford, Connecticut: Dushkin/McGraw-Hill.

Kemper, F. H. C. (1996). Religiositeit, etniciteit en welbevinden bij mannen van de eerste generatie Marokkaanse moslimmigranten [Religiosity, Ethnicity and Well-being among First Generation Moroccan Muslim Immigrants]. Nijmegen: Katholieke Universiteit Nijmegen.

Kim, Y. (1977). Communication patterns of foreign immigrants in the process of acculturation. Human Communication Research, 4(1), 66-77.

Kim, Y. (1980). Explaining acculturation in a communication framework: An empirical test. Communication Monographs, 47, 155-179.

Kim, Y. (1995). Cross-cultural adaptation: An integrative theory. In R. Wiseman (Ed.). International and Intercultural Communication Annual, 19, 170-193. Thousand Oaks, CA: Sage.

Klatter-Folmer, J. (1997) 'Schoolsucces van Turkse kinderen in relatie tot hun sociaalculturele oriëntatie' [School success of Turkish children in relation to their sociocultural orientation]. Migrantenstudies, 13(1), 25-41.

McQuail, D. (1995). New roles for new times? Media Studies Journal, 9(3), 11-19.

Milikowski, M. (1997). Zappen tussen Kluivert en Hakan: Turkse jongeren en satelliet tv [Zapping between Kluivert and Hakan: Turkish youth and satellite tv]. In Jeugd and sub-culturen en nieuwe media [Youth and Subcultures and New media]. Groningen: Unesco and Media GN.

Milikowski, M. (1999). Stoorzender of katalysator?: Turkse satelliet tv in Nederland [Disturber or katalyst?: Turkish satellite television in the Netherlands]. Migrantenstudies, 5 (3), 170-190. 
Milikowski, M. (2000).'Exploring a model of de-ethnicization: The case of Turkish television in the Netherlands'. European Journal of Communication, 15(4), 443468.

Millikowski, M. (1998). Zapping between Dutch and Turkish: Satellite television and Amsterdam Turkish migrants. In Migration and Identity. London: Routledge.

Mullan, B. (1997). Consuming television. Oxford: Blackwell.

Norris, P. (1996). 'Does television erode social capital? A reply to Putnam'. Political Science and Politics, 29(3), 474-480.

Ogan, C. and Milikowski, M. (1998). Television helps to define home for the Turkish women of Amsterdam. Media Development, XLV(3), 13-21.

Peeters, A. and d'Haenens, L. (2005). Bridging or bonding? Relationships between integration and media use among ethnic minorities in the Netherlands. Communications. The European Journal for Communication Research, 30(2), 201-231.

Peñaloza, L. (1994). 'Atravensando fronteras [Border crossings]: A critical ethnographic exploration of the consumer acculturation of Mexican immigrants.' Journal of Consumer Research, 21, 32-54.

Putnam, R. (2000). Bowling alone, the collapse and revival of civic America. New York: Simon and Schuster.

Rios, D. and O'Gaines, S. (1998). Latino media use for cultural maintenance. Journal and Mass Communication Quarterly, 75(4), 746-761.

Robinson, J. P. and Levy, M. R. (1986). The main source: Learning from television news. Beverly Hills, CA: Sage.

Schaap, G., Konig, R., Renckstorf, K. and Wester, F. (2005). Measuring the complexity of viewers' television news interpretation: Differentiation. Communications, 30 (4), 459-475.

Shah, D., Kwak, N. and Holbert, R. L. (2001). 'Connecting' and 'disconnecting' with civic life: The effects of internet use on the production of social capital. Political Communication, 18, 141-162.

Staring, R. and Zorlu, S. (1996). Thuis voor de buis: Turkse migranten en satellietteevee [At home affront of the tube: Turkish migrants and satellite television], Migrantenstudies, 12(4), 211-221.

Subervi-Velez, F., Ramirez Berg, C., Constantakis-Valdes, P., Noriega, C., Rios, D. I. and Wilinson, K. T. (1997). Hispanic-oriented media. In C. E. Rodriguez (Ed.), Latin Looks (pp. 225-237). Boulder, CO: Westview Press.

Subervi-Velez, F. A.(1986). The mass media and ethnic assimilation and pluralism: A review and research proposal with special focus on Hispanics. Communication Research, 13(1), 71-96.

Viswanath, K. and Pamela, A. (2000). Ethnic media in the United States: An essay of their role in integration, assimilation, and social control. Mass Communication and Society, 3(1), 39-56.

Walker, D. (1999). The Media's role in immigrant adaptation: How first-year Haitians in Miami use the media. Journalism and Communication Monographs, 1(3), 158196.

Woelfel, J., Holmes, R., Kincaid, D. L. and Barnett, G. A. (1980). How to do a Galileo study. Troy, NY: Good Books.

Zhou, M. and Cai, G. (2002). 'The Chinese language media in the United States: Immigration and assimilation in American life.' Qualitative Sociology, 25(3), 419-440.

Van Heelsum, A. J. (1997). De etnisch-culturele positie van de tweede generatie Surinamers [Ethnic-Cultural Position of the Second Generation Surinamese]. Amsterdam: Het Spinhuis. 
Veldkamp Market Research. (1998). Tijdsbesteding en mediagebruik allochtone jeugd 1997 [Time Consumption and Media Use among Ethnic Minority Youth - 1997]. Amsterdam: Veldkamp.

Veldkamp Market Research. (1999). Mediagebruik etnische publieksgrepen - 1998. Een onderzoek onder Turkse, Marokkaanse, Surinaamse, Antilliaanse, Chinese en Molukse publieksgroepen van 18 jaar en ouder [Media Use among Ethnic Audience Groups - 1998. Research among Turkish, Moroccan, Surinamese, Antillean, Chinese and Moluccan Audience Groups, Aged 18 and Older]. Amsterdam: Veldkamp. 